\title{
Perancangan dan Realisasi Web-Based Data Logging System menggunakan ATmega16 melalui Hypertext Transfer Protocol ( HTTP)
}

\author{
RATNA SUSANA, ANGGA NUGRAHA, DECY NATALI ANA \\ Teknik Elektro Institut Teknologi Nasional (ITENAS) Bandung \\ Email: ratnassn@yahoo.com
}

\begin{abstract}
ABSTRAK
Hypertext Transfer Protocol (HTTP) merupakan protokol jaringan pada lapisan aplikasi TCP/IP yang menjadi dasar komunikasi pada World Wide Web (WWW). Penelitian ini merancang dan merealisasikan web-based data logging system yang bertujuan untuk memperkenalkan aturan HTTP, sehingga perangkat elektronik dapat berkomunikasi dengan website secara langsung. Sistem dirancang dengan dua sub sistem utama yaitu website data logger dan website. Data logger direalisasikan menggunakan ATMegal6 yang diintegrasikan dengan sumber data analog dan digital, RTC serta modem GSM. Data logger berfungsi sebagai pengirim data, sedangkan website berfungsi sebagai pengatur, penerima, pengolah dan penyaji data. Sistem ini telah berhasil melakukan komunikasi antara data logger dengan website melalui HTTP, artinya protokol ini dapat diimplementasikan pada data logger yang menggunakan ATmega16. Perubahan data analog dan status logika 0 dan 1 dari data digital yang terjadi pada data logger dapat dilihat pada tampilan di website.
\end{abstract}

Kata kunci: basis data, data logger, Hypertext Transfer Protocol (HTTP), website, protokol jaringan.

\begin{abstract}
Hypertext Transfer Protocol (HTTP) is an application layer network protocols in TCP/IP is the basis of communication on the World Wide Web (WWW). This research was to design and realize a web-based data logging system that aims to introduce the rules of HTTP, so that electronic devices could communicate with the website directly. The system was designed with two main sub-system, namely data logger and website. The data logger was realized using ATmegal6 are integrated with analog and digital data sources, RTC and a GSM modem. Data logger function as the sender of data, while the website functions as regulator, receiver, processing and presenter data. This system had been successfully perform communication between the data logger to a website via HTTP, meaning that this protocol could be implemented on a data logger that uses ATmega16. Website could receive and process the data transmitted by the data logger and organize system entities. Changes in analog data and status logic 0 and 1 of digital data could be seen on display at the website.
\end{abstract}

Keywords: database, data logger, Hypertext Transfer Protocol (HTTP), network protocol, website. 


\section{PENDAHULUAN}

Internet merupakan salah satu terapan dari teknologi telekomunikasi yang banyak menggunakanprotokol jaringan berbasiskan Transmission Control Protocol/Internet Protocol (TCP/IP), salah satunya adalah Hypertext Transfer Protocol (HTTP). HTTP merupakan protokol jaringan pada lapisan aplikasi pada TCP/IP yang digunakan untuk komunikasi data di webworld wide web (WWW). Web memiliki fungsi sebagai media penyimpan data dan/atau media publikasi yang dapat diakses dari berbagai perangkat. Proses pengumpulan data dapat dilakukan oleh perangkat elektronik yang disebut data logger.

Data logger merupakan perangkat elektronik berbasiskan prosessor dijital yang memiliki sensor atau terhubung dengan sensor yang berfungsi untuk mencatat data suatu lingkungan yang dilakukan secara berkala (Badhiye, Chatur, $\boldsymbol{\&}$ Wakode, 2011). Data tersebut dapat berupa suatu data input, output atau hasil perhitungan yang dapat disimpan dalam bentuk media penyimpanan internal dan/atau dikirim ke server melalui media komunikasi.

Liu Yanfie merancang ZigBee wireless sensor network yang dapat mengirimkan data dengan jarak jauh secara nirkabel. Pada penelitiannya, sejumlah ZigBee Node Sensor akan mengumpulkan data sensor dan mengirimkannya pada host computer sebagai coordinator sensor melalui media RF ZigBee (Yunhe, 2009). Telah dikembangkan pula suatu aplikasi web based oleh Young-Jun Jeon, dengan merealisasikan sensor node menggunakan mikrokontroler yang terhubung dengan PC sebagai gateway untuk menampung data dari sensor node. Pengiriman data menuju gateway dapat melalui media RS-232, LAN ataupun USB. Selanjutnya data pada PC gateway dikirimkan menuju web server (Jeon, Park, \& Park, 2009). Pada dasarnya, sejumlah data sensor dapat dikirimkan dari mikrokontroler menuju komputer (PC) melalui suatu media komunikasi baik menggunakan kabel maupun tanpa kabel. Konsep inilah yang selanjutnya akan digunakan pada penelitian ini, namun menggunakan media tanpa kabel melalui media komunikasi General Packet Radio Service (GPRS).

Penelitian ini bertujuan untuk merancang dan merealisasikan web-based data logging system, yaitu sebuah sistem pencatatan data terpusat berbasiskan web dan dapat mengirimkan datanya melalui Hyper Text Transfer Protocol (HTTP).

Sistem terbagi menjadi dua sub sistem yaitu data logger dan website. Data logger berfungsi sebagai pengambil dan pengirim data sensor yang dipasang pada data logger, sedangkan website berfungsi sebagai penerima, pengolah dan penyaji data. Proses pengiriman dan penerimaan data harus sesuai dengan aturan HTTP, proses tersebut diatur oleh pengendali yang direalisasikan dengan mikrokontroler ATmega 16. Sub sistem data logger direalisasikan menggunakan mikrokontroler ATmega 16 yang terintegrasi dengan real time clock dan modem GSM. Hasil pencatatan data logger disimpan pada memori internal dan dikirim ke website melalui media internet. Website yang digunakan dalam penelitian ini menampilkan informasi data yang diberikan oleh data logger. Informasi yang diberikan adalah hasil rekapitulasi data sistem yang diamati sehingga menjadi referensi dalam membuat sistem (yang diamati).

Data yang dikirimkan oleh data logger merupakan sumber data baik data analog maupun dijital, yang akan disajikan kepada pengguna layanan sistem. Pengguna layanan sistem merupakan pengguna internet yang telah terdaftar dalam sistem dan menggunakan HTTP client yang mendukung HyperText Markup Language(HTML), Cascading Style Sheets (CSS) dan bahasa pemrograman Javascript. 


\section{PERANCANGAN DAN REALISASI SISTEM}

\subsection{Gambaran Umum Sistem}

Web-based data logging system yang penulis rancang terdiri dari dua bagian yaitu client dan server. Perancangan client (data loggen) yang meliputi perangkat keras serta perangkat lunak sedangkan perancangan server (website) meliputi perancangan web serta database. Adapun blok diagram sistem yang dirancang dapat dilihat pada Gambar 1.

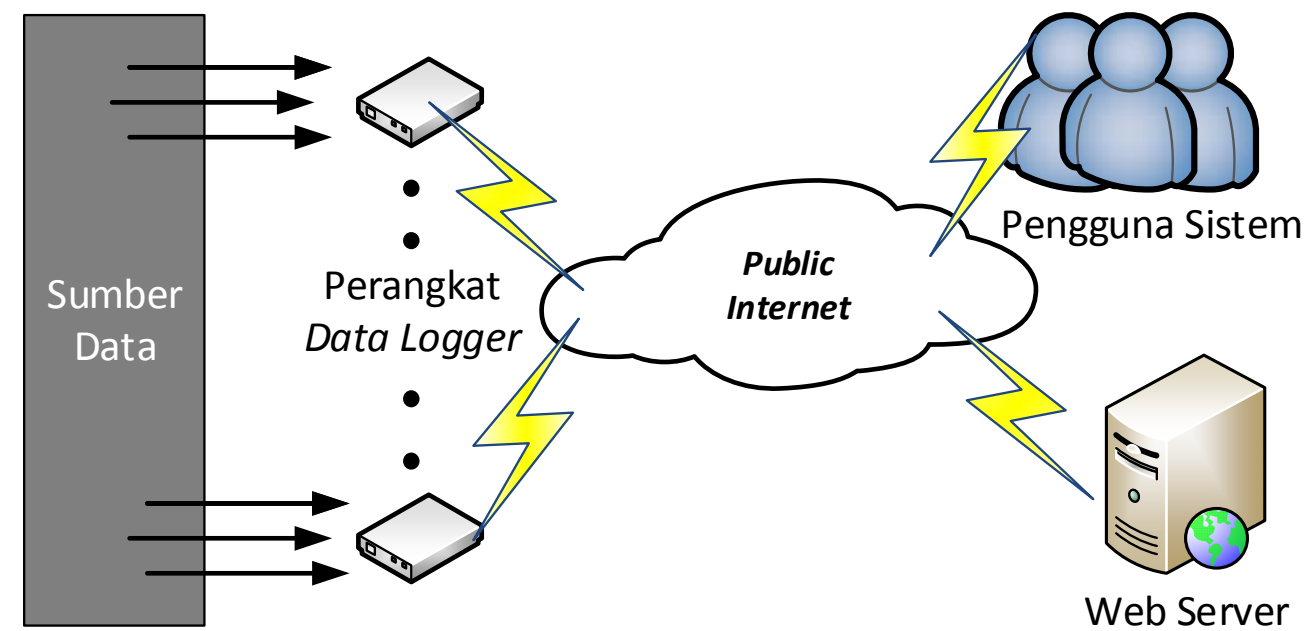

Gambar 1. Blok sistem yang dirancang

Sistem yang dirancang dapat mengakomodasi lebih dari satu data logger. Akan tetapi dalam penelitian ini hanya merealisasikan satu buah data logger, dengan blok diagram seperti pada Gambar 2.

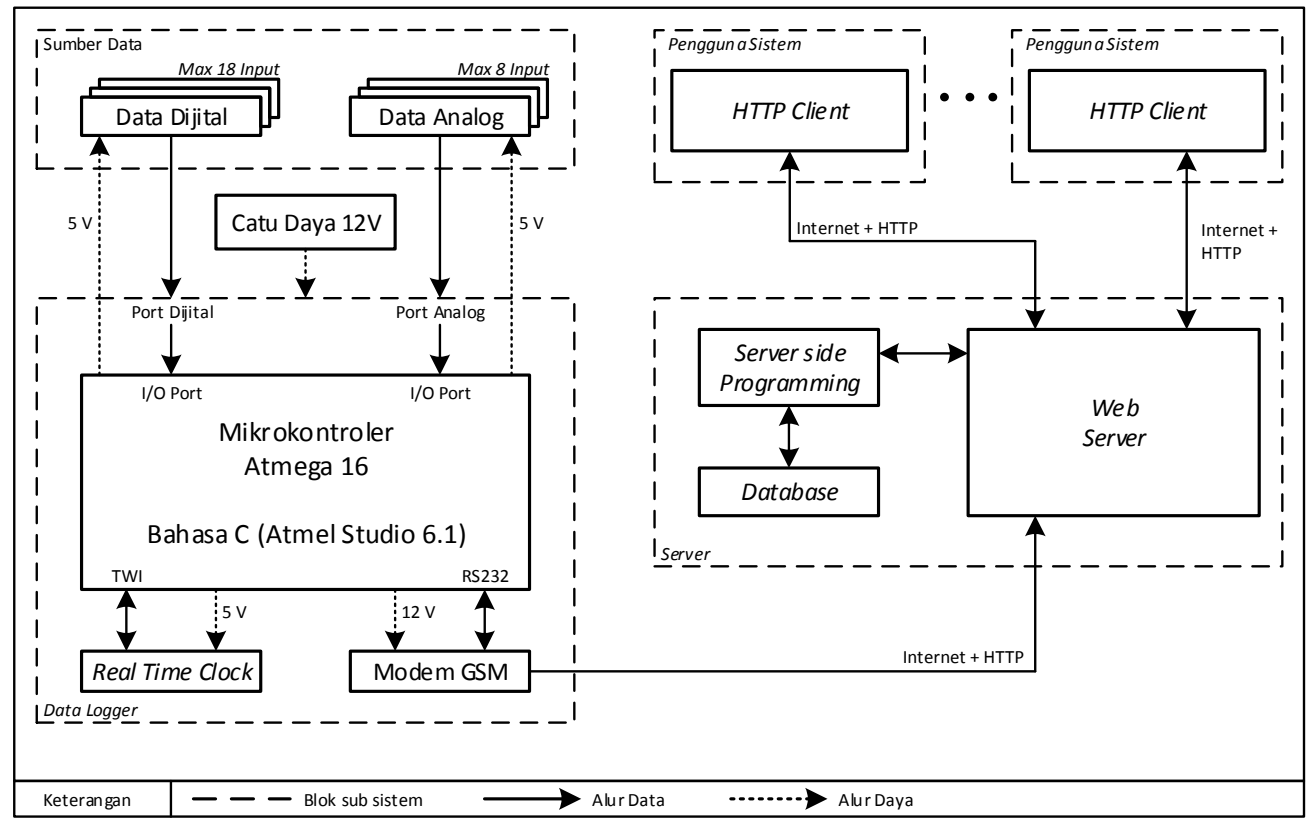

Gambar 2. Blok sistem yang direalisasikan 


\subsection{Spesifikasi Sistem}

Spesifikasi sistem perancangan meliputi spesifikasi untuk 3 (tiga) sub sistem yaitu:

1. Spesifikasi Sub Sistem Data Logger, yang dirancang adalah:

a. Menggunakan mikrokontroler sebagai pengendali.

b. Menggunakan memori internal sebagai media penyimpanan sementara.

c. Sumber data pada data logger berasal dari sensor analog dan sensor dijital.

d. Data yang dikirimkan dilengkapi dengan informasi waktu.

e. Menggunakan modem GSM dengan fitur TCP/IP stack untuk komunikasi data ke website.

f. Periode pengambilan data dilakukan secara periodik dari satu menit sampai dengan satu jam.

g. Protokol pengiriman data ke server menggunakan komunikasi data HTTP dengan metode POST.

h. Menggunakan catu daya sebesar 12 volt.

2. Spesifikasi Sub Sistem Website, yang dirancang adalah:
a. Memiliki domain name
b. Memiliki web hosting
c. Memiliki akses internet
d. Menggunakan HTTP server yang mendukung bahasa pemrograman PHP

3. Spesifikasi Sub Sistem Pengguna Sistem, yang dirancang pengguna harus memiliki koneksi internet serta menggunakan HTTP client yang mendukung sebagai berikut:
a. Mendukung bahasa pemograman Hyper Text Markup Language (HTML)
b. Mendukung Cascading Style Sheets (CSS)
c. Mendukung bahasa pemrograman Javascript

\subsection{Cara Kerja Sistem}

Cara kerja sistem secara keseluruhan mulai dari data logger, website dan pengguna sistem dapat dilihat pada Gambar 3. Proses kerja sistem berdasarkan urutan nomor pada Gambar 3.

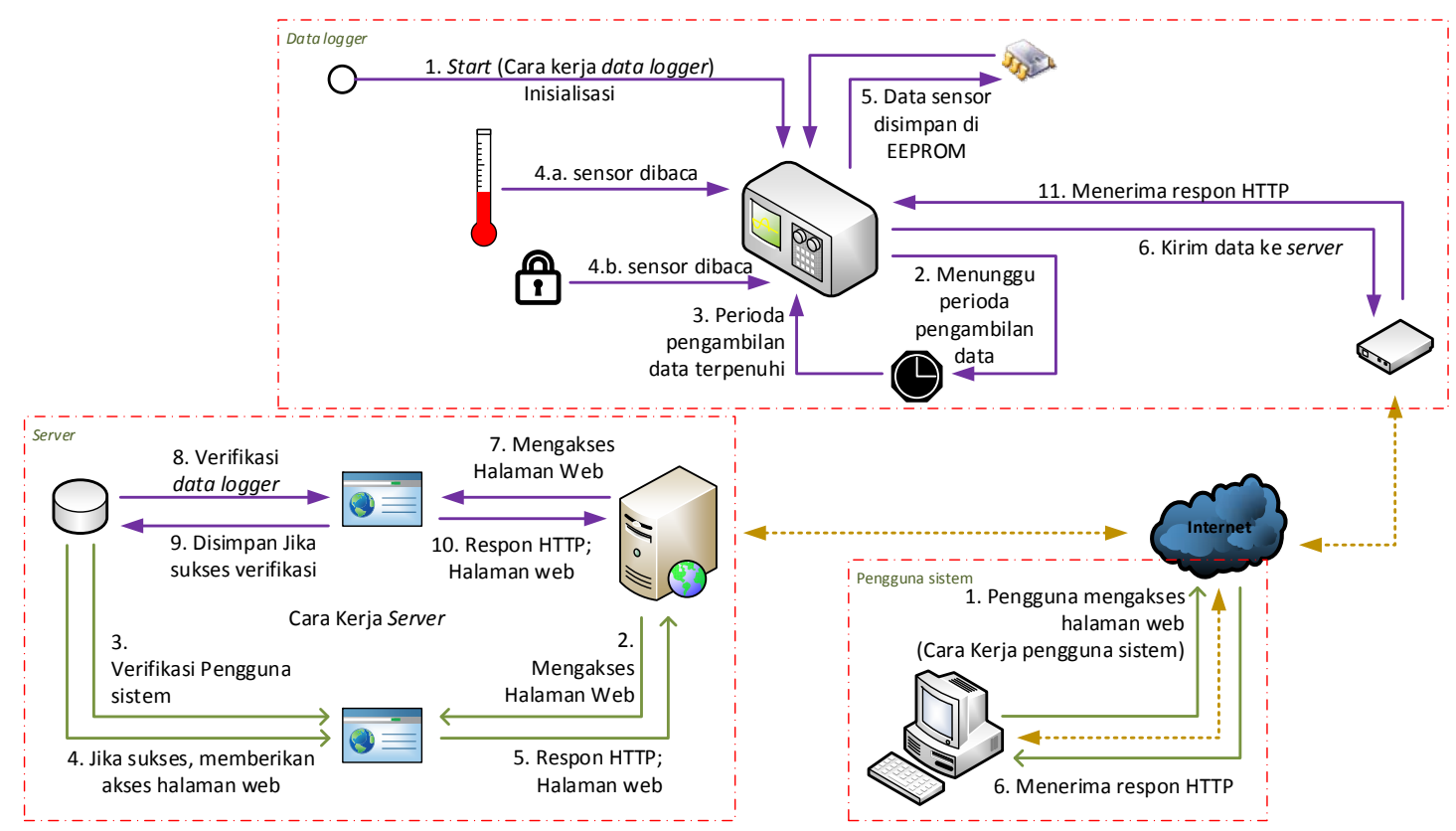

Gambar 3. Cara kerja sistem 


\subsection{Perancangan dan Realisasi Sub Sistem Data Logger}

Perancangan dan realiasi sub sistem data logger terdiri dari perangkat keras dan perangkat lunak.

\subsubsection{Perancangan dan Realisasi Perangkat Keras}

Pembuatan data logger yang terdiri dari beberapa tahapan, yaitu melakukan modifikasi sistem minimum mikrokontroler ATmega menjadi modul pengendali, membuat antarmuka modul pengendali dengan modul Real Time Clock (RTC), antarmuka modul pengendali dengan modul modem dan pembuatan perangkat elektronik untuk sumber data. Perangkat elektronik untuk sumber data terdiri dari perangkat elektronik analog yang diimplementasikan oleh sensor suhu serta perangkat elektronik dijital yang diimplementasikan oleh saklar yang tersedia pada modul pengendali.

\subsubsection{Perancangan dan Realisasi Perangkat Lunak}

Mikrokontroler merupakan komponen pada bagian data logger yang dikendalikan oleh program. Program tersebut berfungsi untuk mengatur lalu lintas data pada data logger, seperti pengambilan, penyimpanan data sensor serta pengiriman data ke server. Program dibuat menggunakan perangkat lunak Atmel Studio versi 6.1, yang terdiri dari beberapa sub program yaitu inisialisasi, membaca konfigurasi, membaca data dari sensor serta mengirimkan data ke server. Gambar 4 merupakan flowchart program utama pada mikrokontroler.

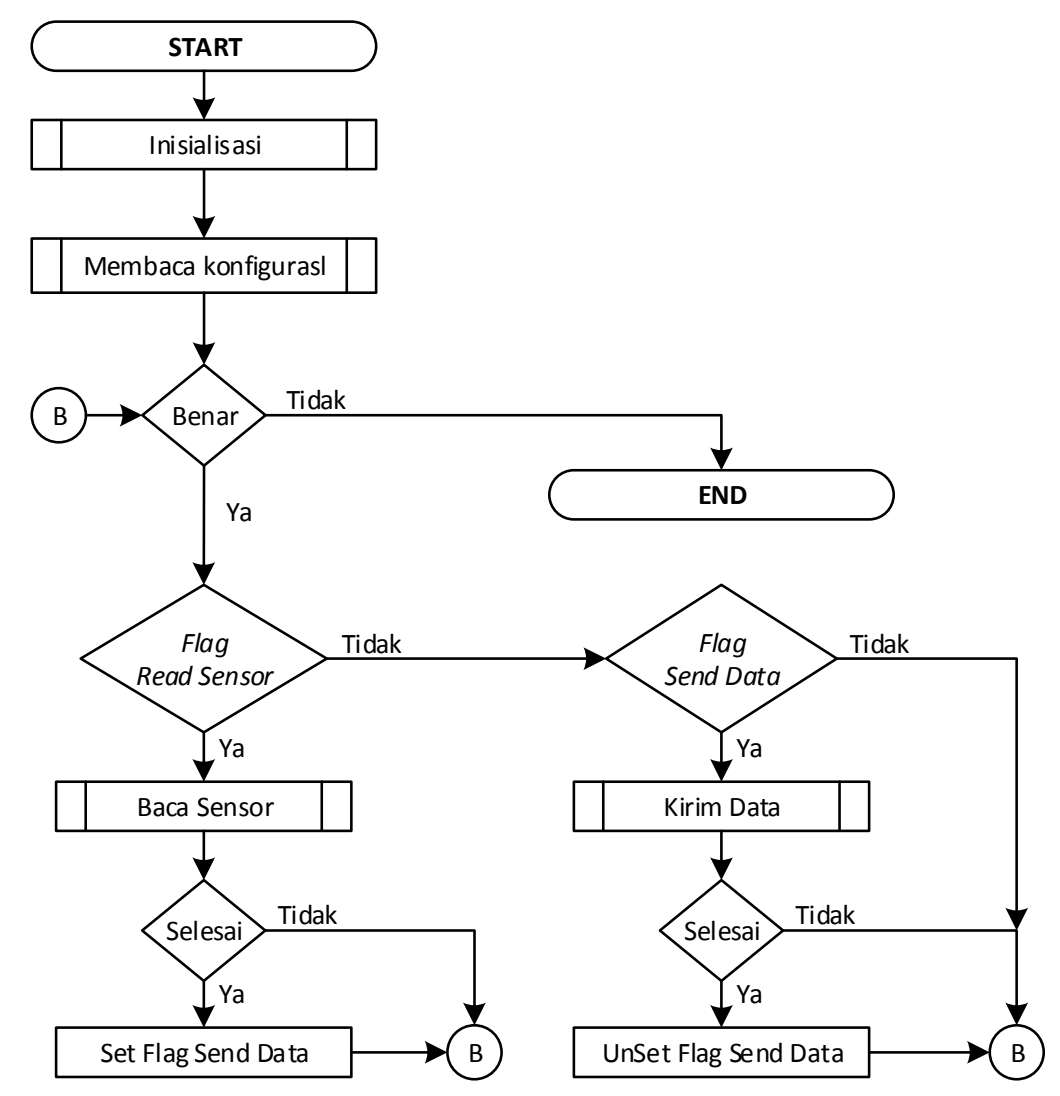

Gambar 4. Flowchart program utama pada mikrokontroler

\subsection{Perancangan dan Realisasi Sub Sistem Server}

\subsubsection{Tahapan Perancangan Web Server}

Data Flow Diagram (DFD) level 0 menggambarkan sistem yang akan dirancang sebagai entitas tunggal yang berinteraksi dengan sistem lainnya. DFD Level 0 digunakan untuk menjelaskan interaksi sistem yang dirancang dengan entitas luar. 
Penulis menggambarkan DFD level 0 sistem yang dirancang seperti pada Gambar 5.

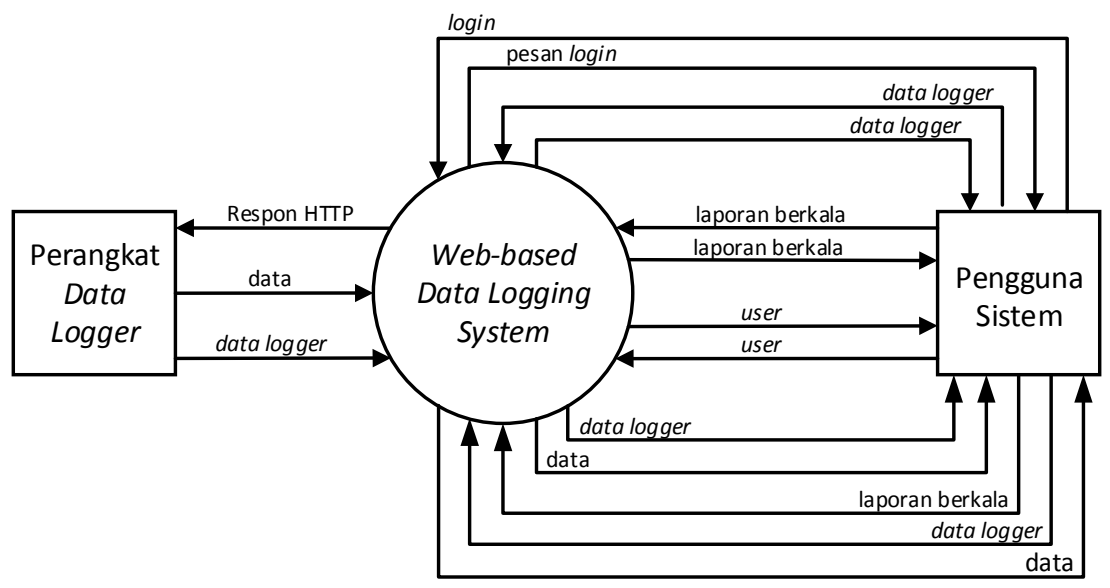

Gambar 5. Data Flow Diagram level 0

Sistem yang dirancang memiliki dua entitas yaitu entitas perangkat data logger dan pengguna sistem. Perangkat data logger merupakan perangkat elektronik yang mengirimkan data dari lingkungan yang diamati, sedangkan pengguna sistem adalah pengguna/pengelola dari data logging system.

\subsubsection{Tahapan Perancangan Database Server}

Perancangan pada database server memiliki 3 tahapan yaitu Entity Relationship Diagram (ERD), Physical Data Model (PDM) dan implementasi. Berikut akan dijelaskan tahapan yang dikerjakan.

\section{Entity Relationship Diagram (ERD)}

Entity Relationship Diagram (ERD) merupakan model data yang berupa notasi grafis dalam pemodelan data konseptual yang menggambarkan hubungan entitas. Sistem yang dirancang memiliki 4 entitas yaitu user, data logger (data logger, sensor, satuan), data dan laporan berkala. Untuk lebih jelasnya dapat dilihat pada Gambar 6.

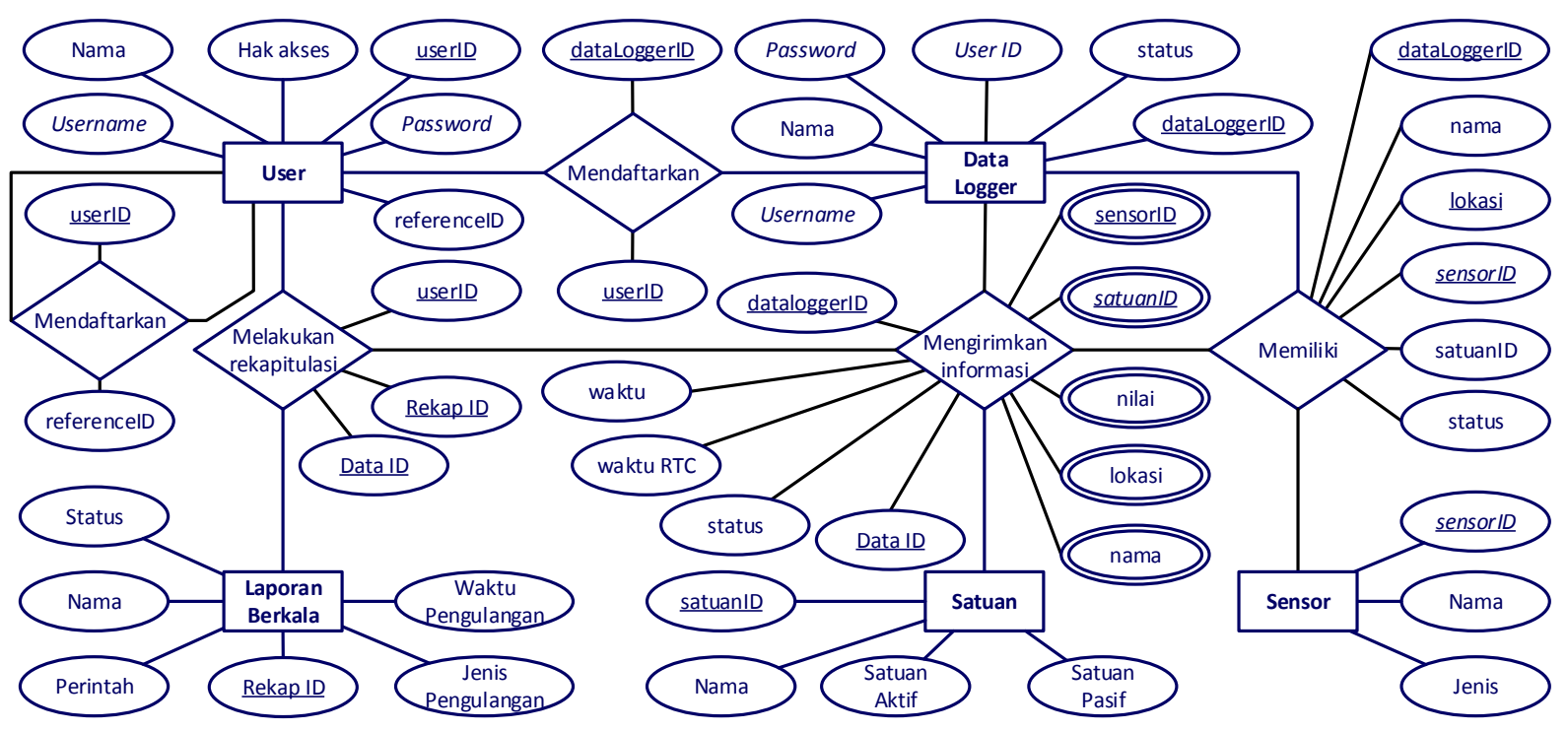

Gambar 6. Entity Relationship Diagram (ERD) sistem 


\section{Physical Data Model (PDM)}

Physical Data Model (PDM) merupakan data model yang menggunakan sejumlah tabel untuk menggambarkan dan menghubungkan data-data yang digunakan oleh sistem yang disertai jenis kunci (key) dan jenis data. PDM menerangkan bagaimana data disimpan dalam database. PDM sistem yang dibangun dapat dilihat pada Gambar 7.

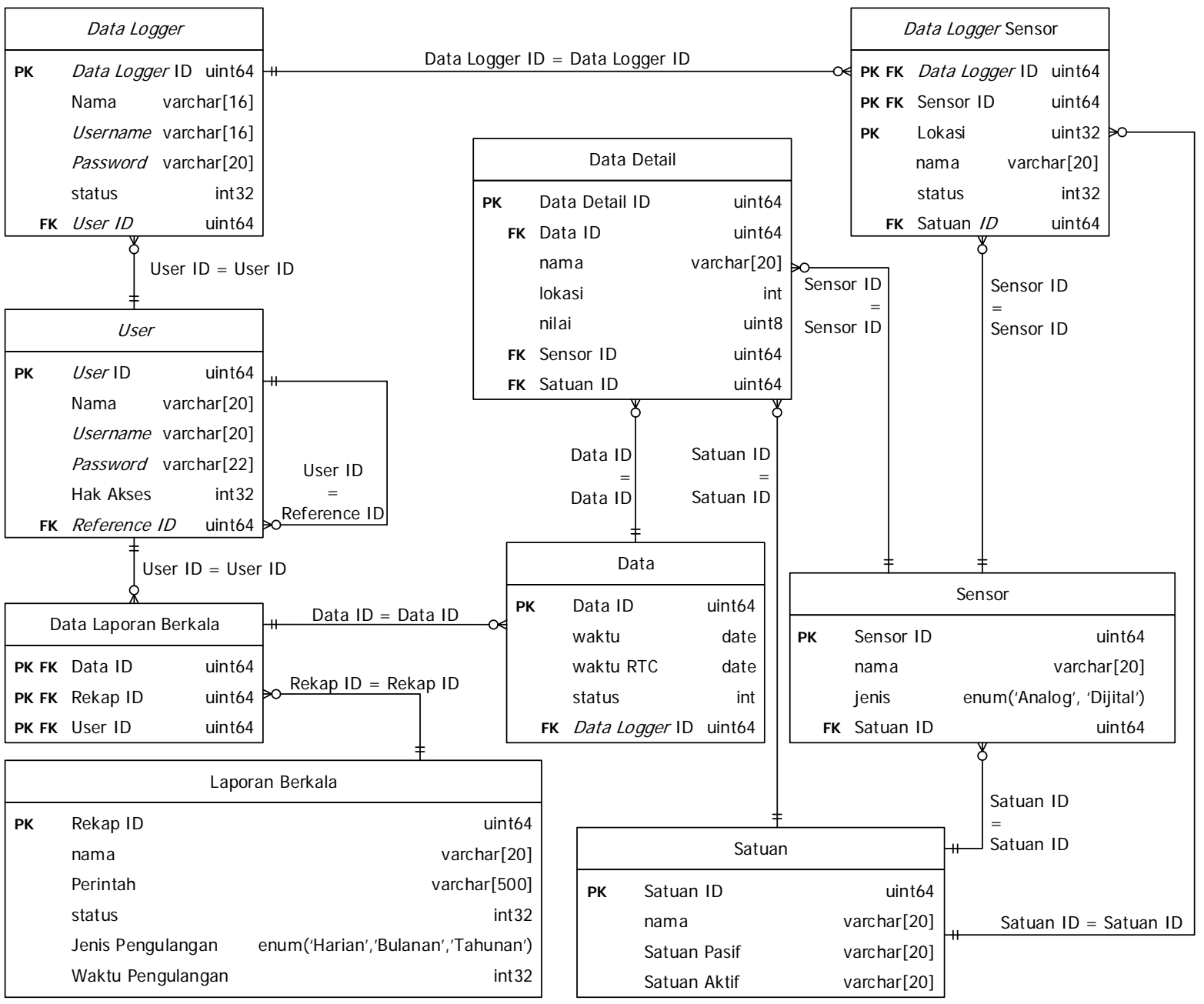

\section{Gambar 7. Physical Data Model sistem}

\section{I mplementasi}

Setelah melakukan tahapan Physical Data Model (PDM) maka tahapan selanjutnya mengubah struktur database menjadi Data Definition Language (DDL). Data Definition Language (DDL) merupakan bahasa pemprograman untuk mendefinisikan struktur, khususnya database. DDL yang digunakan dalam membangun sistem dalam penelitian ini adalah Structured Query Language (SQL).

\subsection{Perancangan Format Data}

Format penyimpanan (memori internal mikrokontroler) dan pengiriman data adalah sebagai berikut:

\section{Format Penyimpanan Data Pada Memori Internal Mikrokontroler}

Format data penyimpanan memori internal mikrokontroler merupakan kumpulan dari konfigurasi datalogger serta data hasil pengambilan dari sensor. Tabel 1 menjelaskan alokasi memori yang digunakan. Konfigurasi pada Tabel 1, hanya berlaku dengan kondisi input 
analog sebanyak 1 sensor dan input dijital maksimum 8 sensor dalam satu port, dengan urutan data dapat dilihat pada Tabel 2.

Tabel 1. Format alokasi memori internal mikrokontroler

\begin{tabular}{|lll|}
\hline \multicolumn{2}{|c|}{ Alamat Memori } & \multicolumn{1}{c|}{ Variabel } \\
\hline $0000 \mathrm{H}$ & $-001 \mathrm{~F} \mathrm{H}$ & Alamat Server \\
\hline $0020 \mathrm{H}$ & $-002 \mathrm{~F} \mathrm{H}$ & User agent \\
\hline $0030 \mathrm{H}$ & $-003 \mathrm{~F} \mathrm{H}$ & Access Point Name (APN) \\
\hline $0040 \mathrm{H}$ & $-0049 \mathrm{H}$ & Username APN \\
\hline $004 \mathrm{~A} \mathrm{H}$ & $-0053 \mathrm{H}$ & Password APN \\
\hline $0054 \mathrm{H}$ & $-0054 \mathrm{H}$ & Durasi \\
\hline $0055 \mathrm{H}$ & $-0058 \mathrm{H}$ & Konfigurasi Dijital \\
\hline $0059 \mathrm{H}$ & $-0059 \mathrm{H}$ & Konfigurasi Analog \\
\hline $005 \mathrm{~A} \mathrm{H}$ & $-0062 \mathrm{H}$ & Data sensor (hasil pengambilan dari senror) ke-1 \\
\hline $0063 \mathrm{H}-006 \mathrm{~B} \mathrm{H}$ & Data sensor ke-2 \\
\hline $006 \mathrm{H}-0074 \mathrm{H}$ & Data sensor ke-3 \\
\hline & $:$ & $:$ \\
\hline $01 \mathrm{EF} \mathrm{H}-01 \mathrm{~F} 7 \mathrm{H}$ & Data sensor ke-46 \\
\hline $01 \mathrm{~F} 8 \mathrm{H}$ & $-0200 \mathrm{H}$ & Data sensor ke-47 \\
\hline
\end{tabular}

Tabel 2. Urutan data hasil pengambilan dari sensor

\begin{tabular}{|l|c|c|c|c|c|c|c|c|c|}
\hline Byte Ke & 1 & 2 & 3 & 4 & 5 & 6 & 7 & 8 & 9 \\
\hline Data & \multicolumn{1}{|c|}{ Informasi Waktu } & & Data Analog & Data Dijital \\
\hline
\end{tabular}

Tabel 2 menjelaskan urutan pengiriman data, berupa informasi waktu, data analog dan data dijital. Informasi waktu memiliki data sebesar 5 byte dengan distribusi bit-nya yang dapat dilihat pada Gambar 8.

\begin{tabular}{|c|c|c|c|c|c|c|c|c|c|c|c|c|c|c|c|c|}
\hline Bit Ke & 39 & 38 & 37 & 36 & 35 & 34 & 33 & 32 & 31 & 30 & 29 & 28 & 27 & & & \\
\hline Data & 0 & 0 & \multicolumn{7}{|c|}{ Tahun } & \multicolumn{4}{|c|}{ Bulan } & & & \\
\hline Bit Ke & 26 & 25 & 24 & 23 & 22 & 21 & 20 & 19 & 18 & 17 & 16 & 15 & 14 & 13 & 12 & 11 \\
\hline Data & \multicolumn{5}{|c|}{ Tanggal } & \multicolumn{5}{|c|}{ Jam } & \multicolumn{6}{|c|}{ Menit } \\
\hline Bit Ke & 10 & 9 & 8 & 7 & 6 & 5 & 4 & 3 & 2 & 1 & 0 & & & & & \\
\hline Data & \multicolumn{6}{|c|}{ Detik } & 0 & 0 & 0 & 0 & 0 & & & & & \\
\hline
\end{tabular}

Gambar 8. Distribusi bitinformasi waktu pada penyimpanan memori internal

Data analog memiliki data sebesar 2 byte dengan distribusi bit datanya dapat dilihat pada Gambar 9.

\begin{tabular}{|l|c|c|c|c|c|c|c|c|c|c|c|c|c|c|c|c|}
\hline Bit Ke & 15 & 14 & 13 & 12 & 11 & 10 & 9 & 8 & 7 & 6 & 5 & 4 & 3 & 2 & 1 & 0 \\
\hline Data & $\mathbf{0}$ & $\mathbf{0}$ & $\mathbf{0}$ & $\mathbf{0}$ & $\mathbf{0}$ & \multicolumn{10}{|c|}{ Pin } & \multicolumn{10}{|c|}{ Data } \\
\hline
\end{tabular}

Gambar 9. Distribusi bit data analog 
Data dijital memiliki data sebesar 2 byte dengan distribusi bit datanya dapat dilihat pada Gambar 10.

\begin{tabular}{|l|c|c|c|c|c|c|c|c|c|c|c|c|c|c|c|c|}
\hline Bit Ke & 15 & 14 & 13 & 12 & 11 & 10 & 9 & 8 & 7 & 6 & 5 & 4 & 3 & 2 & 1 & 0 \\
\hline Data & $\mathbf{0}$ & $\mathbf{0}$ & $\mathbf{1}$ & Port & $\mathbf{0}$ & $\mathbf{0}$ & $\mathbf{0}$ & \multicolumn{1}{|c|}{ Data } \\
\hline
\end{tabular}

\section{Gambar 10. Distribusi bit data dijital}

\section{Format Pengiriman Data}

Pengiriman data dari data logger menuju web server harus sesuai dengan aturan HTTP. Tabel 6 menjelaskan format data yang akan dikirim dari data logger menuju web server.

Tabel 6. Format pengiriman data dari data logger ke web server

\begin{tabular}{ll}
\hline \multicolumn{1}{c}{ Jenis Data } & \multicolumn{1}{c}{ Contoh } \\
\hline Metode Pengiriman Data & POST /dev/inputdata.php HTTP/1.1 \\
\hline Tujuan & Host: datalogger.tk \\
\hline User-agent & c455b9c4dfd3e2cdd448b0e7b7b1f9ec \\
\hline Jenis koneksi & Connection: close \\
\hline Jumlah karakter data & Content-Length: 18 \\
\hline Jenis data & Content-Type: application/x-www-form-urlencoded \\
\hline Blank Line & \\
\hline Data & data=\$G氏 $\$ T . a ̀ \$ @ \$ X$ ü \\
\hline
\end{tabular}

\section{PENGUJ IAN DAN ANALISIS}

\subsection{Metoda Pengujian}

Metode pengujian sistem yang dilakukan penulis yaitu melakukan pengujian setiap sub sistem secara terpisah berupa pengujian data logger dan website. Setelah masing-masing sub sistem diuji sesuai dengan perancangan, maka dilakukan pengujian keseluruhan sistem.

\subsection{Pengujian Sub Sistem Data Logger}

\subsubsection{Pengujian Circular Buffer}

Circular buffer merupakan media penyimpanan data sementara di mikrokontroler yang dihasilkan dari proses komunikasi serial UART dengan server melalui modem. Pengujian dilakukan menggunakan perangkat lunak Hercules versi 3.2.6 dengan mengirimkan sejumlah karakter, dengan tahapan sebagai berikut :

1. Data logger menerima data kurang dari 200 karakter dan sistem harus mengirimkan data tersebut secara utuh.

2. Data logger menerima data lebih dari 200 karakter dan sistem harus tidak mengirimkan data. 
Gambar 11 dan 12 menunjukkan hasil pengiriman data circular buffer yang dilakukan.

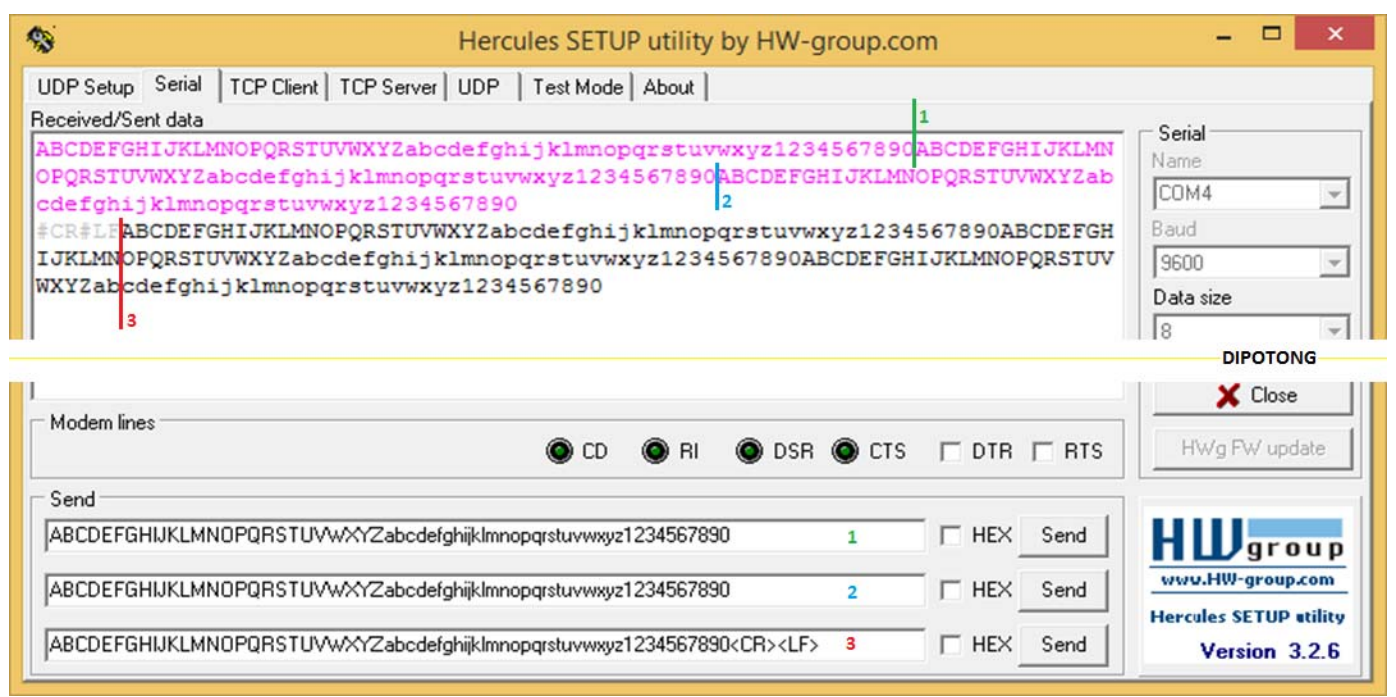

Gambar 11. Pengujian circular buffer kurang dari 200 karakter

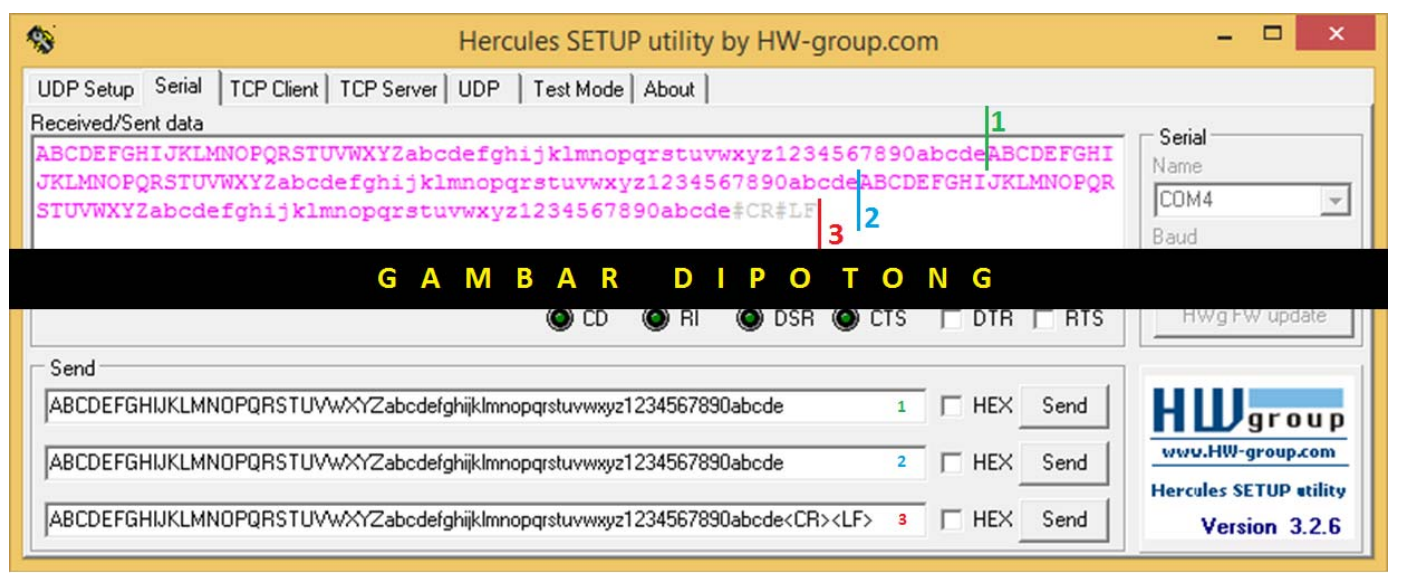

\section{Gambar 12. Pengujian circular buffer lebih dari 200 karakter}

\subsubsection{Pengiriman data menuju server}

Pengujian pengiriman data menuju server dengan cara data logger akan mengirimkan data sensor dijital ke alamat http://datalogger.tk/input/test.php dengan periode satu menit. Sumber data berasal dari port $\mathrm{C}$ pin 2 dan 3 yang diatur kondisinya oleh saklar push button yang berada di port $\mathrm{D}$ pin 2 dan 3. Pada proses pengiriman data, indikator pengiriman data dimulai penulis menyalakan LED pin 7 dan akan mematikan LED tersebut 10 detik setelah pengiriman selesai. Hal ini dilakukan untuk memudahkan dalam pendokumentasian. Hasil dari pengujian didapat data pada server telah menunjukan kondisi yang sama dengan kondisi pada data logger. Hasil dari pengujian ini adalah website dapat menerima dan menampilkan data yang dikirimkan oleh data logger. 
Gambar 13 menunjukkan proses pengujian pengiriman data ke server.

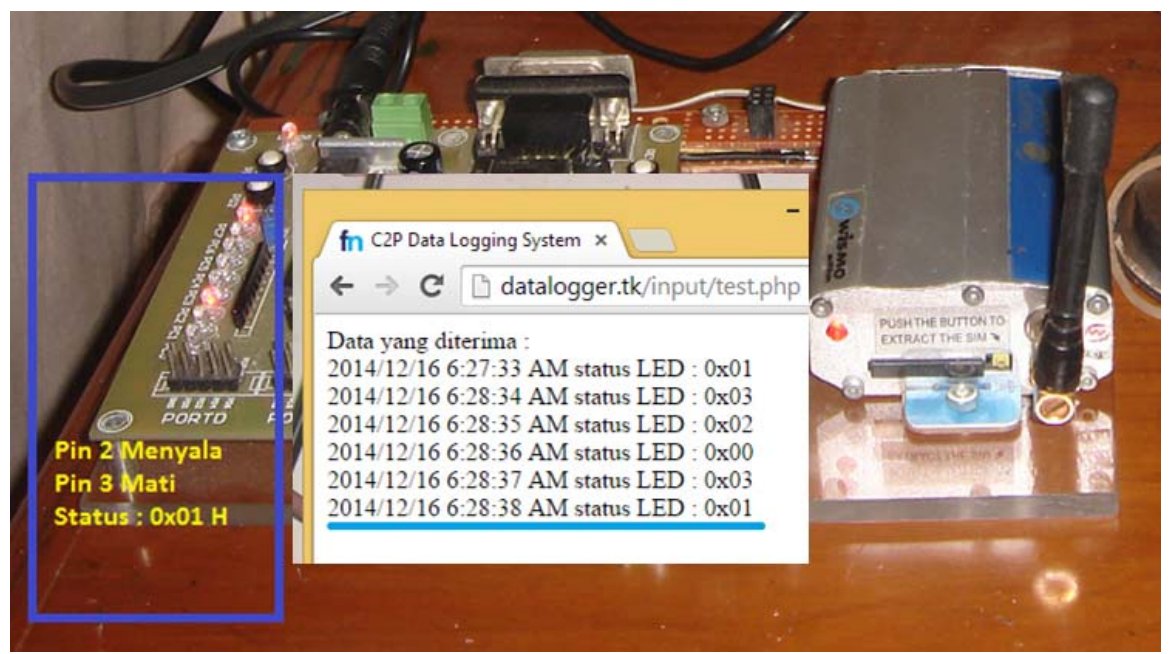

Gambar 13. Pengujian pengiriman data ke server

\subsection{Pengujian Website}

\subsubsection{Pengujian Halaman Website Khusus Data Logger}

Pengujian ini bertujuan untuk mengetahui bahwa halaman web untuk data logger hanya dapat diakses oleh perangkat data logger terdaftar. Website akan membandingkan useragent HTTP client data logger dengan database dan meresponnya dengan status HTTP. Gambar 14 menunjukkan website menolak sedangkan Gambar 15 menunjukkan website menerima permintaan akses halaman dari HTTP client.

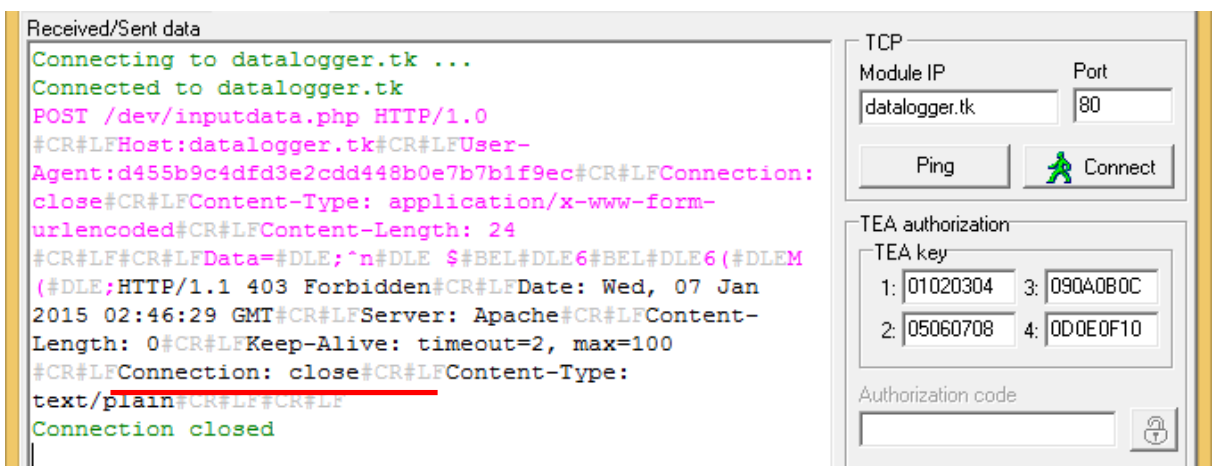

Gambar 14. Website menerima data loggeryang tidak terdaftar di server
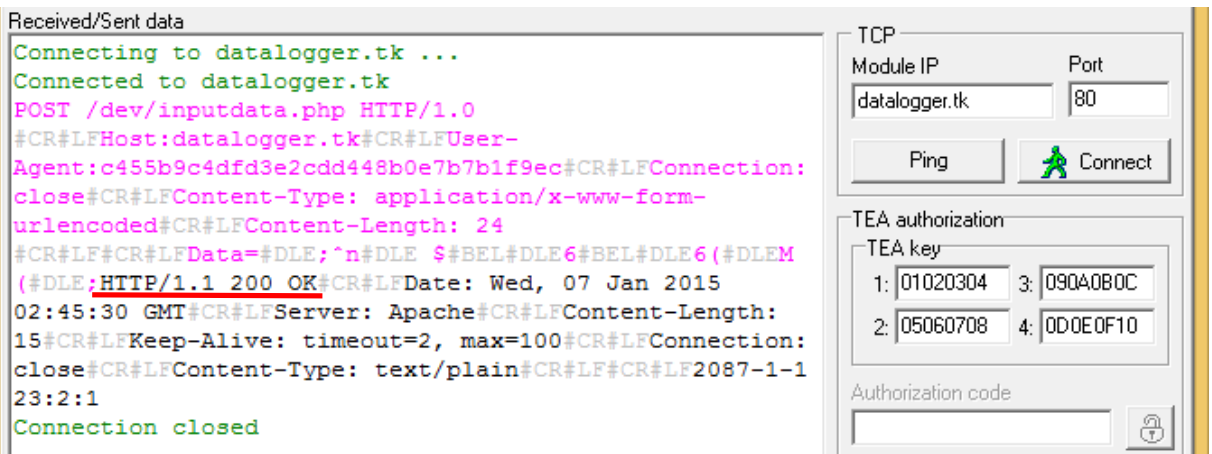

Gambar 15. Website menerima data logger yang telah terdaftar di server 


\subsubsection{Pengujian Halaman Website}

Pengujian ini bertujuan untuk mengetahui bahwa website telah sesuai dengan rancangan DFD, ERD dan PDM yang dirancang. Gambar 13 menunjukkan bahwa website dapat menampilkan data perangkat data logger, sedangkan Gambar 14 menunjukkan bahwa website dapat menampilkan data pengguna sistem.

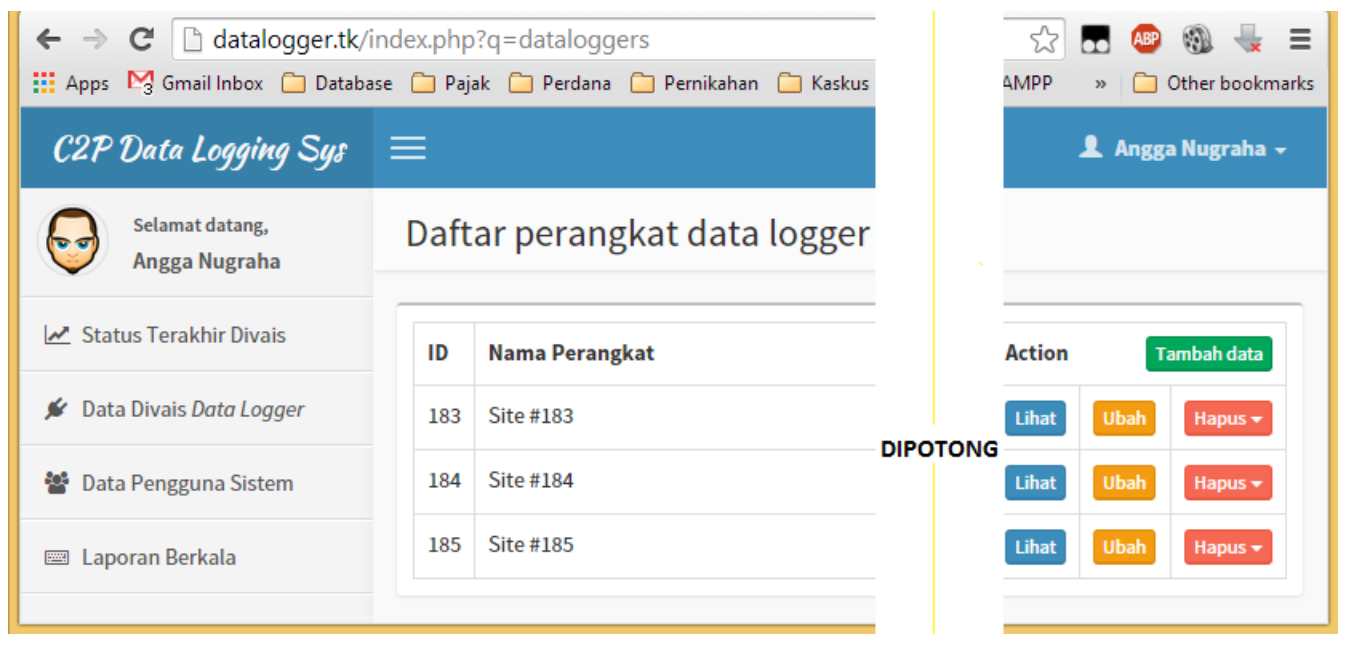

Gambar 16. Website menampilkan perangkat data logger

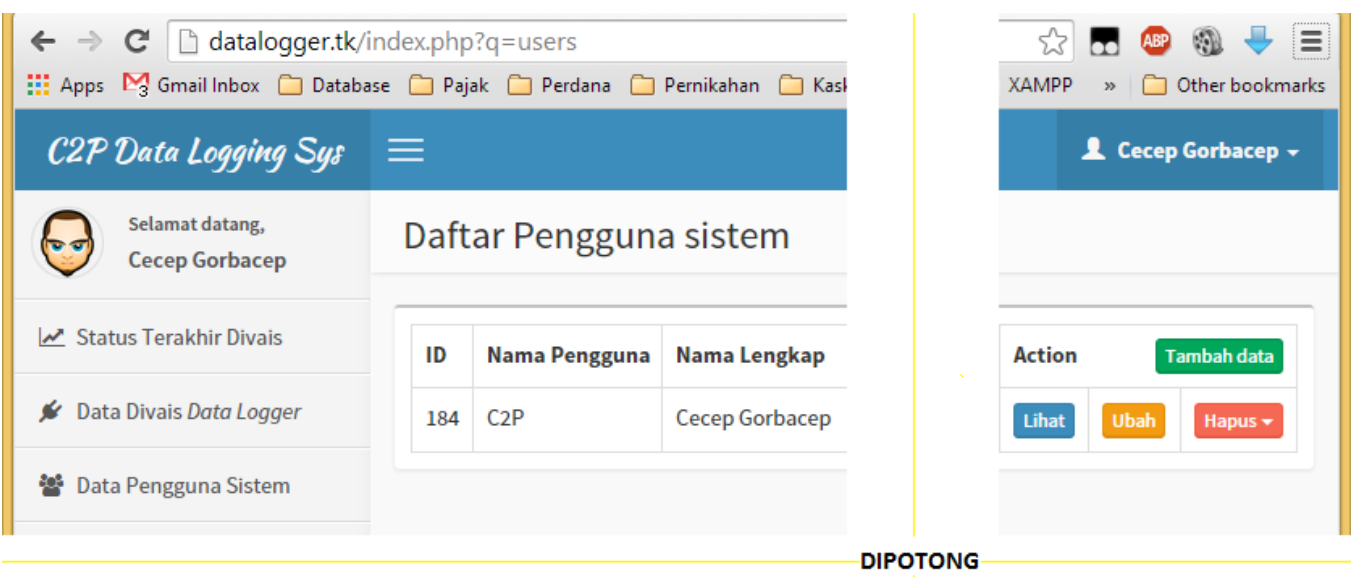

Gambar 17. Website menampilkan data pengguna sistem

\subsection{Pengujian keseluruhan sistem}

Pengujian ini merupakan kelanjutan dari pengujian pada sub bab 3.2.2 yaitu pengiriman data ke server. Hasil dari pengujian pada sub bab 3.2.2 hanya menampilkan data yang dikirim oleh data logger, sedangkan pengujian keseluruhan sistem, data yang dikirim oleh data logger telah diproses, sehingga data yang ditampilkan telah menjadi informasi. Pengujian dilakukan dengan cara memfungsikan data logger sampai dengan melakukan pengiriman data sensor sehingga website dapat menampilkan informasi kondisi data logger sesuai data yang dikirimkan. Ketika proses pengiriman data dari data logger menuju website, data yang dikirim menuju modem diambil menggunakan kabel tapping yang dipasang diantara data logger dengan modem. Data hasil tapping merupakan format pengiriman data menggunakan aturan HTTP yang diapit oleh perintah AT Command TCP/IP Stack yang berfungsi untuk membuat dan memutuskan koneksi dengan website. 
Gambar 18 menunjukkan hasil tapping data pada saat data logger mengirimkan data ke website.

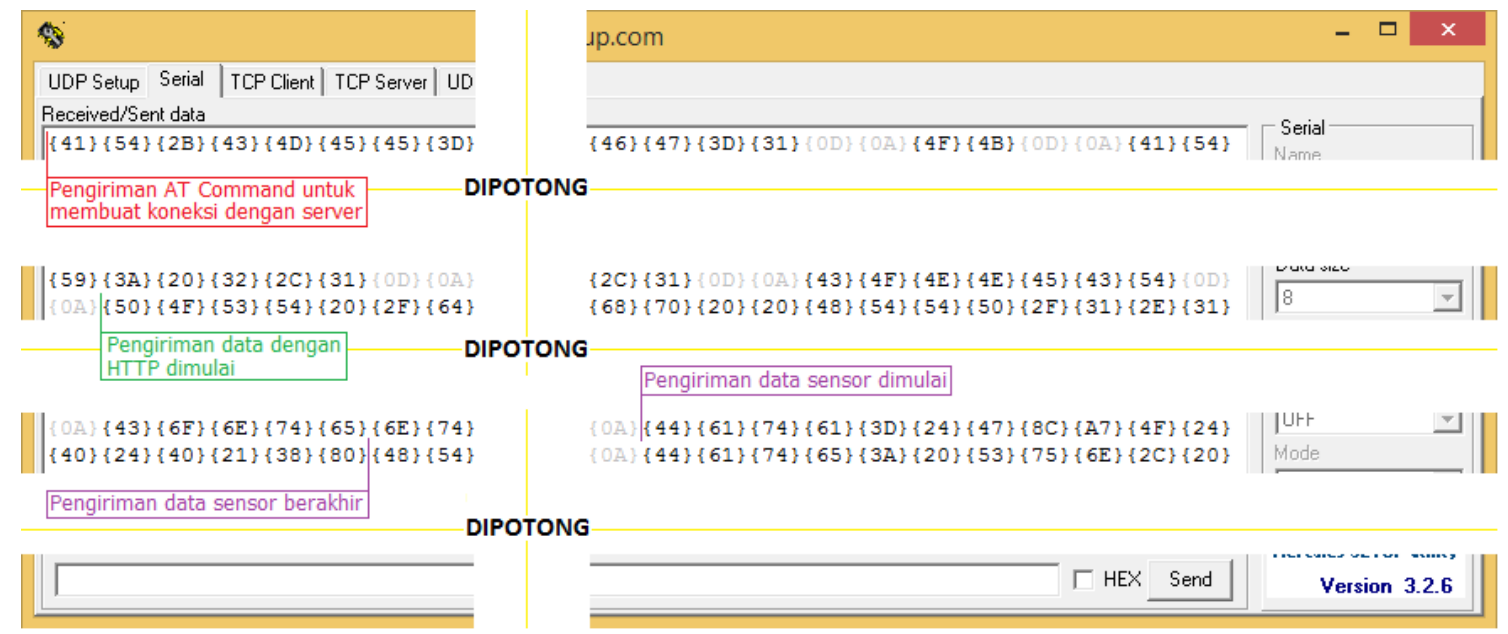

Gambar 18. Proses tapping data

Gambar 19 menunjukkan website menampilkan informasi dari data sensor yang dikirim oleh data logger

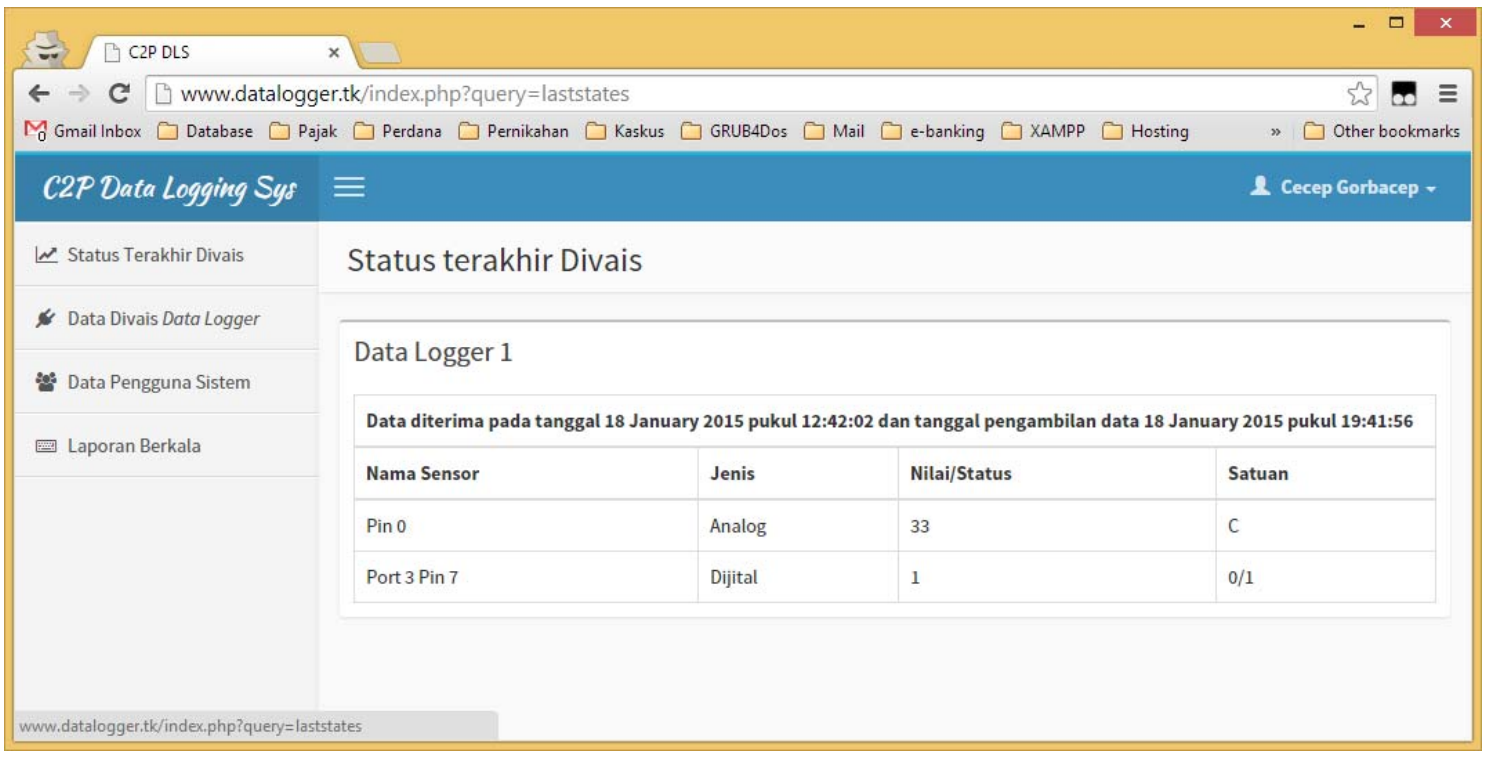

Gambar 19. Website menampilkan informasi data yang dikirimkan oleh data logger

Untuk menjamin kesesuaian informasi yang disediakan oleh website dengan kondisi aktual data sensor yang dikirimkan oleh data logger, maka dilakukan verifikasi informasi dengan informasi yang dihasilkan dari proses tapping. Pengolahan data hasil proses tapping secara umum terdapat dua tahapan. Tahapan pertama adalah memisahkan data sensor yang terdapat pada data hasil proses tapping. Tahapan kedua adalah mengubah data sensor menjadi informasi sesuai dengan format data yang dijelaskan pada Tabel 2. 
Pada pengujian ini, proses pengubahan data sensor menjadi informasi dapat dilihat pada Gambar 20.

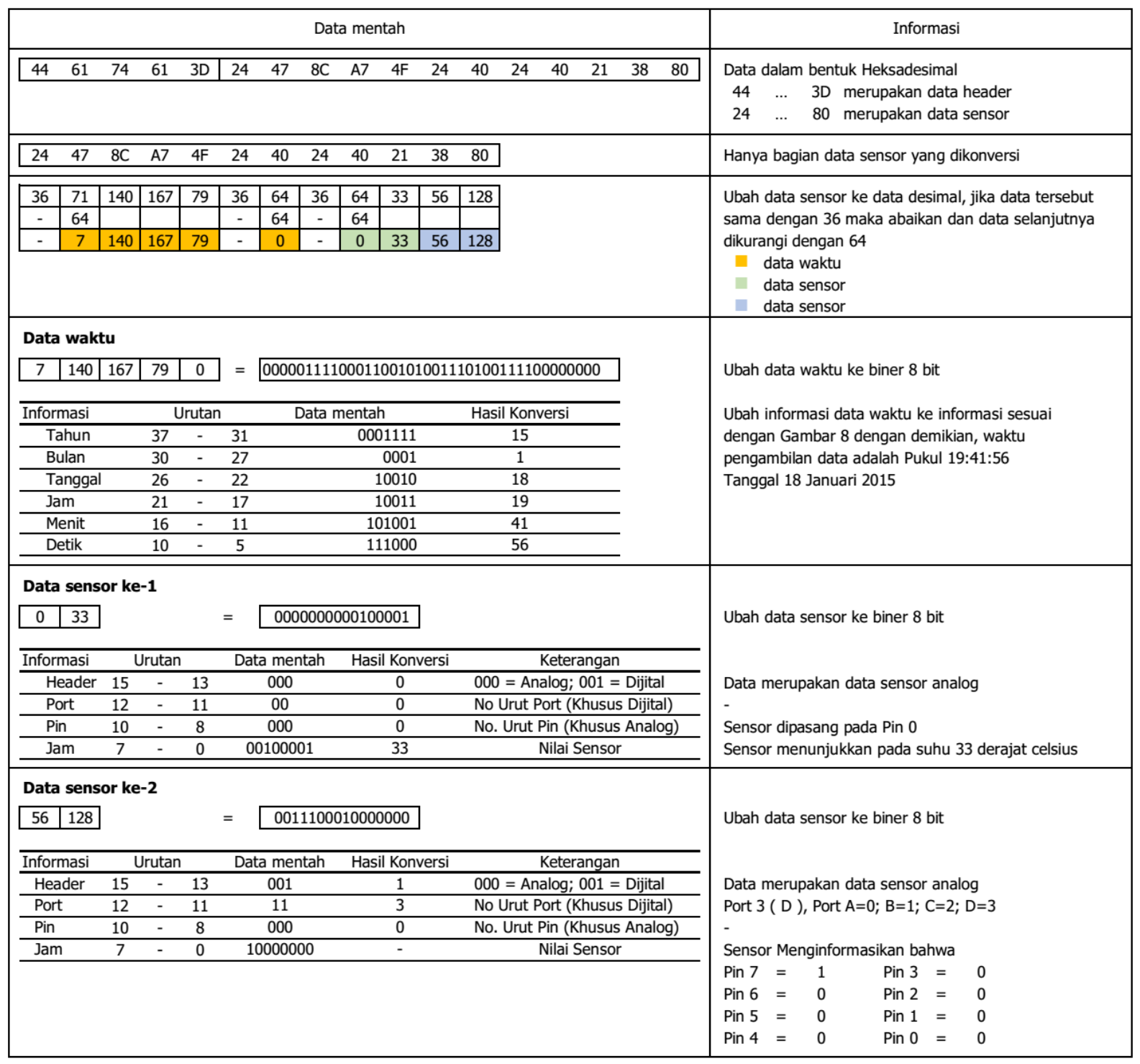

Gambar 20. Proses perhitungan data hasil tapping menjadi informasi

\section{KESI MPULAN}

Berdasarkan perancangan, realisasi dan hasil pengujian sistem yang telah dilakukan, maka penelitian ini dapat disimpulkan sebagai berikut:

1. Data logger berkomunikasi dengan website. Hal ini berdasarkan dengan pengujian pengiriman ke server. Hypertext terminal protocol (HTTP) dapat implementasikan pada data logger.

2. Website dapat menampilkan dan mengatur data pengguna sistem, data logger sesuai dengan pengujian halaman website.

3. Website dapat mengolah dan menampilkan data yang dikirim oleh data logger sesuai dengan pengujian keseluruhan sistem. 


\section{DAFTAR RUJ UKAN}

Badhiye, S. S., Chatur, P. N., \& Wakode, B. V. (2011). Data Logger System: A Survey. International Journal of Computer Technology and Electronics Engineering (IJCTEE), 24-26.

J eon, Y.-J., Park, S.-H., \& Park, J.-S. (2009). Sensor Node Middleware to Support Web-Based Applications over Wireless Sensor Networks. Proceeding The $2^{\text {nd }}$ IEEE Workshop on Wireless and Internet Service (WISe 2009) Zurich Swizerland, 20 - 23 Oktober 2009 963-970.

The Internet Engineering Task Force (IETF $\left.{ }^{\circ}\right)$. (2012, Agustus 10). Hypertext Transfer Protocol -- HTTP/1.1. Retrieved from The Internet Engineering Task Force: http://tools. ietf.org/pdf/rfc2616.pdf

Wahana Komputer. (2006). Panduan lengkap menguasai pemograman web dengan PHP 5. Yogyakarta: ANDI.

Winoto, A. (2010). Mikrokontroler AVR ATmega8/32/16/8535 dan Pemogramannya dengan Bahasa C pada WinAVR. Bandung: Informatika.

Yunhe, L. Y. (2009). An Improved Design of ZigBee Wireless Sensor Network. Dipetik pada tanggal 3 February 2014 jam 12.44 pp. 515-518 dari http://ieeezplorer.ieee.org 